\title{
An optimized DNA extraction and multiplex PCR for the detection of Fasciola sp. in lymnaeid snails
}

\author{
Y. Caron ${ }^{\mathrm{a}, *}$, S. Righi ${ }^{\mathrm{b}}$, L. Lempereur ${ }^{\mathrm{a}}$, C. Saegerman ${ }^{\mathrm{c}}$, B. Losson $^{\mathrm{a}}$ \\ a Research Unit in Parasitology and Parasitic Diseases, Department of Infectious and Parasitic Diseases, Faculty of Veterinary Medicine, University of Liège, \\ B-4000 Liège, Belgium \\ b Veterinary Sciences Institute, University Center of El Tarf, B.P 73000 El Tarf, Algeria \\ c Research Unit in Epidemiology and Risk Analysis applied to Veterinary Sciences (UREAR), Department of Infectious and Parasitic Diseases, \\ Faculty of Veterinary Medicine, University of Liège, B-4000 Liège, Belgium
}

\section{A R T I C L E I N F O}

\section{Article history:}

Received 27 July 2010

Received in revised form 9 December 2010

Accepted 15 December 2010

\section{Keywords:}

Fasciola sp.

Lymnaea sp.

Chelex $^{\circledR}$

Phenol/Chloroform/Proteinase K

Multiplex PCR

Epidemiology

\begin{abstract}
A B S T R A C T
This study deals with the development and validation of an original PCR protocol to assess the presence of Fasciola hepatica in Galba truncatula its main intermediate host in Western Europe. In the present study two DNA extraction techniques are compared and a new multiplex PCR is described. The Chelex ${ }^{\circledR}$ DNA extraction technique showed to be more appropriate than the classical Phenol/Chloroform/Proteinase $\mathrm{K}$ based method because of the absence of toxic organic solvent, shorter duration and lower cost, and a higher reproducibility regarding DNA concentrations and wavelength ratios. The multiplex PCR was set up to amplify the lymnaeid internal transcribed spacer 2 sequence (500-600 bp) that act as an internal control and a $124 \mathrm{bp}$ Fasciola sp. sequence that is repeated more than 300,000 times in fluke whole genome. Ninety six snails were pooled and 6 snails (6.25\%) found positive for Fasciola sp. The limit of detection is lower than the minimal biological infestation unit (one miracidium). DNA extracts from Paramphistomum daubneyi, Dicrocoelium lanceolatum, and Fascioloides magna did not cross react.
\end{abstract}

(c) 2010 Elsevier B.V. All rights reserved.

\section{Introduction}

Fasciola hepatica, the common liver fluke is a widely distributed parasitic helminth. Fasciolosis affects mainly domestic ruminants and is responsible for important economic losses. In a recent study the financial loss due to bovine fasciolosis in Switzerland reached approximately 52 million Euros per year (Schweizer et al., 2005).

Galba truncatula is the main lymnaeid intermediate host in the Old World (Taylor, 1965; Torgerson and Claxton, 1999) but most of the other lymnaeid species of Western Europe may also sustain the larval development of the liver fluke if they are exposed to miracidia during their first days of life (Boray, 1978). For example, Radix labiata was found

\footnotetext{
* Corresponding author. Tel.: +32 436640 09; fax: +32 43664097 .

E-mail address: ycaron@ulg.ac.be (Y. Caron).
}

to act as an alternative intermediate host of $F$. hepatica, at least under laboratory conditions, because it harboured the intra-molluscan development and allowed the subsequent shedding of cercariae. Furthermore, these metacercariae were as infective in a rat model as those produced in $G$. truncatula as judged by parasitological and serological data (Caron et al., 2007). These laboratory results should be confirmed in the field in naturally infected potential intermediate hosts.

To determine the ability of a snail species or a snail population to act as intermediate host, quick, cheap, and reliable tools are required. All steps regarding DNA extraction must be reliable and reproducible. The protocol generally used to extract the DNA from snails is based on Phenol/Chloroform extraction and proteinase K (Kaplan et al., 1995; Mostafa et al., 2003; Velusamy et al., 2004; Bargues et al., 2007). The main drawbacks of this technique are the requirement of toxic organic solvents (phenol, 
chloroform), multiple tube transfers, a minimum of three centrifugations, duration (overnight incubation), and cost. Nontoxic techniques based on commercially available spincolumn kits exist and are currently used but are quite expensive and show varied quality. Twenty years ago, procedures based on the use of Chelex ${ }^{\circledR}$ chelating resin were developed for extracting DNA from forensic-type samples (Walsh et al., 1991). Later, this resin was used to extract the DNA from oyster (Ko et al., 1999) but never from lymnaeid snails.

The easiness and relatively low cost of the basic PCR protocol make it interesting to investigate the epidemiology of liver fluke infections (Caron et al., 2008) particularly during large epidemiological surveys dealing with big samples (>1000 snails). Consequently, several PCR protocols were developed to assess Fasciola sp. prevalence in lymnaeid snails (Krämer and Schnieder, 1998, 1999; Krämer, 1999; Mostafa et al., 2003; Velusamy et al., 2004; Cucher et al., 2006; Caron et al., 2007). Real-time PCR (Schweizer et al., 2007) and multiplex PCR were also developed (Magalhaes et al., 2004, 2008). This last technique is very interesting because several sequences were amplified in the same PCR tube. Indeed, the PCR technique has to take into account the possibility of false negative results because of PCR inhibitors. Therefore, an internal control can be amplified along with the gene of interest.

The aim of this study was first, to compare DNA extraction based either on Chelex ${ }^{\circledR}$ or Phenol/Chloroform/Proteinase $\mathrm{K}$ and second, to develop a multiplex PCR to detect accurately Fasciola sp. infection in confirmed potential snail intermediate hosts.

\section{Materials and methods}

\subsection{DNA extractions}

The DNA of one hundred G. truncatula collected in July 2007 in the region of Boutheldja (a hyperendemic area in Algeria) was extracted following two DNA extraction methods (each whole snail was divided with a scalpel blade in two equal parts):

\subsubsection{Phenol/Chloroform/Proteinase K-based DNA extraction method}

The snail was mechanically disrupted with a scalpel blade in $100 \mu$ l of water in Petri dishes and incubated at $50^{\circ} \mathrm{C}$ overnight in $100 \mu \mathrm{l}$ of lysis buffer $(50 \mathrm{mM}$ TrisHCl pH 8, $100 \mathrm{mM} \mathrm{NaCl}, 50 \mathrm{mM}$ EDTA, 0.8\% SDS) and $200 \mu \mathrm{g} / \mathrm{ml}$ proteinase $\mathrm{K}$ (Promega). Thereafter, $100 \mu \mathrm{l}$ of phenol/chloroform/isoamyl-alcohol (25/24/1) was added to the initial mix. The mixture was placed on a vortex for one minute and centrifuged at $12,000 \times g$ for one minute. The supernatant was transferred to a microcentrifuge tube containing $100 \mu \mathrm{l}$ of chloroform/isoamyl-alcohol (24/1), gently mixed and centrifuged at $12,000 \times g$ for ten minutes. The supernatant was transferred into another microcentrifuge tube containing $250 \mu$ l of ethanol $100 \%$ and $50 \mu \mathrm{l}$ of sodium acetate ( $3 \mathrm{M})$, incubated overnight at room temperature and then centrifuged at $12,000 \times \mathrm{g}$ for $30 \mathrm{~min}$. The pellet was washed with $250 \mu \mathrm{l}$ of ethanol $75 \%$ and centrifuged at $12,000 \times g$ for $10 \mathrm{~min}$, dried for sev- eral minutes, rehydrated in water $(100 \mu \mathrm{l})$ and stored at $-20^{\circ} \mathrm{C}$.

\subsubsection{Chelex ${ }^{\circledR}$-based DNA extraction method}

The material was mechanically disrupted with the help of a pellet mixer (TreffLab) in $100 \mu \mathrm{l}$ of Chelex ${ }^{\circledR} 5 \%$ (BioRad) and incubated one hour at $56^{\circ} \mathrm{C}$ and $30 \mathrm{~min}$ at $95^{\circ} \mathrm{C}$ in a Peltier Thermal Cycler (MJ Research). Then the mixture was centrifuged at $13,000 \times g$ for seven minutes. The supernatant was collected and stored at $-20^{\circ} \mathrm{C}$.

The concentrations and the DNA purity (260/280 wavelength ratio) of both DNA series were measured with a spectrophotometer (Thermo Scientific, NanoDrop 1000). Moreover the time required for each techniques and the cost were also evaluated.

\subsection{Multiplex PCR}

The DNA of ninety six G. truncatula collected in April 2008 in the region of Boutheldja (Algeria) was extracted with Chelex ${ }^{\circledR}$ as described above.

This multiplex PCR assay amplifies the highly repeated 124 bp DNA Fasciola sp. specific sequence (Kaplan et al., 1995; Caron et al., 2007) and the rDNA ITS-2 sequence of the snail (500-600 bp). The primers used were, for Fasciola sp. Fsh1 (sense) 5'-GAT-CAA-TTC-ACC-CAT-TTCCGT-TAG-TCC-TAC-3' and Fsh2 (antisense) 5'-AAA-CTGGGC-TTA-AAC-GGC-GTC-CTA-CGG-GCA-3', and for ITS-2 News2 (sense) $5^{\prime}$-TGT-GTC-GAT-GAA-GAA-CGC-AG-3' and Its2Rixo (antisense) 5'-TTC-TAT-GCT-TAA-ATT-CAG-GGG3' (Almeyda-Artigas et al., 2000; Bargues et al., 2001). Different primer concentrations were tested and the best result was obtained with $5 \mu \mathrm{M}$ for Fasciola sp. primer set and $50 \mu \mathrm{M}$ for ITS-2 primer set. The sequences were amplified using a commercial kit (Taq PCR Master Mix, Qiagen) containing $\mathrm{MgCl}_{2}(3 \mathrm{mM})$ and $400 \mu \mathrm{M}$ of each dNTP. Amplification was performed in a total volume of $25 \mu \mathrm{l}$ in a Peltier Thermal Cycler (MJ Research) with an initial denaturation step at $95^{\circ} \mathrm{C}$ for five minutes, followed by 40 denaturation cycles at $95^{\circ} \mathrm{C}$ for one minute, annealing at $56^{\circ} \mathrm{C}$ for one minute, extension at $72{ }^{\circ} \mathrm{C}$ for one minute and a final extension at $72^{\circ} \mathrm{C}$ for ten minutes. The amplification products were electrophoretically resolved in $2 \%$ agarose gels and stained with ethidium bromide. The ITS- 2 band acts as an internal control because its absence indicates the presence of PCR inhibitors.

To reduce the number of PCR, ten pools (nine pools of ten snails and one pool of six snails) were prepared by mixing one $\mu l$ of each DNA sample. This mixture was considered as undiluted. One $\mu l$ of the mixture was then tested in the multiplex PCR described above. To assess the possible influence of PCR inhibitors (when the ITS-2 band was not present), $1 / 10$ and $1 / 100$ dilutions were tested both on pooled and individual samples.

\subsection{Limit of detection}

To assess the limit of detection of the multiplex PCR, two experiments were conducted. In the first one, a pool (pool 9) containing the DNA of one snail naturally infested (100 ng) and the DNA of nine uninfected snails (100 ng 
Table 1

Comparison of phenol/chloroform and Chelex ${ }^{\circledR}$ based DNA extraction (100 G. truncatula).

\begin{tabular}{|c|c|c|c|c|}
\hline & $\begin{array}{l}\text { DNA concentration } \\
(\mathrm{ng} / \mu \mathrm{l})\end{array}$ & $\begin{array}{l}\text { Wavelength } \\
\text { ratio }(260 / 280)\end{array}$ & $\begin{array}{l}\text { Estimated processing } \\
\text { time }(\mathrm{h})\end{array}$ & $\begin{array}{l}\text { Estimated cost } \\
(€ / \text { snail })\end{array}$ \\
\hline Phenol/chloroform & $56.3 \pm 33.1^{*}$ & $1.96 \pm 0.21^{*}$ & 36 & 0.4 \\
\hline Chelex $^{\circledR}$ & $80.0 \pm 25.2^{*}$ & $1.63 \pm 0.07^{*}$ & 5 & 0.2 \\
\hline
\end{tabular}

" Two-sample Wilcoxon rank-sum test, statistically significant with $P=0.0001$.

each) was ten fold diluted until the disappearance of both signals.

In the second experiment, F. hepatica DNA was added to G. truncatula DNA. The amount for the snail DNA was $100 \mathrm{ng}$ in each PCR mixture but the trematode DNA was ten fold diluted (from $100 \mathrm{ng}$ ) until the disappearance of Fasciola sp. specific signal.

\subsection{Specificity}

The DNA of three trematodes (Paramphistomum daubneyi, Dicrocoelium dendriticum, and Fascioloides magna) using G. truncatula as intermediate host and different species of domesticated or wild ruminants as definitive host were tested in the multiplex PCR in order to evaluate the occurrence of possible cross reactions. P. daubneyi and $D$. dendriticum were furnished by the necropsy rooms of the Faculty of Veterinary Medicine of Liège and the Regional Animal Health Investigation Center in Ciney (Belgium) respectively. F. magna was kindly provided by Prof. A. Marinculic from the Faculty of Veterinary Medicine of Zagreb (Croatia). The DNA was extracted with the Chelex ${ }^{\circledR}$ technique and amplified with the multiplex PCR protocol as described above.

Right after a multiplex PCR on a non-infected snail the ITS2 DNA sequence was cloned in a plasmid vector using a commercial kit (pcDNA3.1/V5-His-TOPO TA Expression kit, Invitrogen) following the manufacturer's recommendations. The clones containing the sequence were purified with a commercial kit (NucleoSpin Plasmid, Macherey Nagel) as described by the manufacturer. Then, the ITS2 sequence was sequenced with a genetic analyzer (ABI PRISM ${ }^{\circledR} 3100$, Applied Biosystem) and compared with the BLASTn genomic database (Zhang et al., 2000). The sequence presenting the highest identity was considered as the most probable identification.

Additionally, the $124 \mathrm{bp}$ Fasciola hepatica specific probe was sequenced after amplification through multiplex PCR of an infected snail. The DNA was purified using MSBSpin PCRapace (Invitek). Cycle sequencing reactions were performed by BigDye terminator v3.1 (3730 DNA analyzer; Applied Biosystems) by Giga Genomics Facility (Liège University, Belgium) and the sequence was compared to available database as previously described.

\subsection{Statistical analysis}

\subsubsection{DNA extractions}

The correlation of DNA concentration or purity between both DNA extraction methods (Phenol/Chloroform or Chelex $^{\circledR}$ ) was assessed by the Pearson correlation method (r). A two-sample Wilcoxon rank-sum (Mann-Whitney) test was used to compare the distribution of the DNA concentration values and the wavelength ratio in both Phenol/Chloroform and Chelex ${ }^{\circledR}$ extraction methods (Dagnelie, 1998). The limit of statistical significance of the tests was defined as $P \leq 0.05$.

\section{Results}

\subsection{DNA extractions}

For the comparison of the DNA concentration and purity, $100 \mathrm{G}$. truncatula were used (2 series of matched samples). The DNA concentration values were correlated for both extraction methods $(r=0.32, P=0.001)$ but were significantly higher for the Chelex ${ }^{\circledR}$ extraction method (Two-sample Wilcoxon rank-sum test, $P<0.0001$ ) (Table 1 and Fig. 1A). Moreover the dispersion of DNA concentrations around the mean value was higher for phenol extraction method. The purity in both phenol/chloroform and Chelex ${ }^{\circledR}$ extraction methods were also correlated $(r=0.22, P=0.03)$ (Table 1 and Fig. 1B) but were significantly higher for the phenol extraction method (Two-sample Wilcoxon rank-sum test, $P<0.0001$ ). Similarly, the dispersion of purity around the mean value was higher for phenol extraction method.

\subsection{Multiplex PCR}

Several dilutions were necessary to observe the internal control signal both in the pools and individual samples.

Two pools out of the ten analyzed were positives for Fasciola sp. (both dilution 1/10) (Fig. 2). The DNA from the twenty snails from both positive pools (eight and nine) was examined individually through the multiplex PCR (Figure not shown). Six snails out of ninety six (6.25\%) harboured Fasciola sp. DNA. Noteworthy the ladder pattern is visible for the positive pools and snails. The inhibition rates were calculated both for pooled and individual DNA samples. Concerning pooled and individual samples, the inhibition rate decreased when the dilution factor increased. Respectively, for pooled samples, no diluted (100\%), 10 fold dilution (30\%) and 100 fold dilution (0\%), for individual samples, no diluted (70\%), 10 fold dilution (14\%) and 100 fold dilution $(0 \%)$.

\subsection{Limit of detection}

One pool (\#9) (Fig. 3) containing the DNA from one $F$. hepatica naturally infected snail and 9 negative specimens was used to assess the detection limit of the Fasciola sp. assay. The technique was able to detect up to a total DNA concentration of $100 \mathrm{pg}$. At a total DNA concentration of 
A

Chelex



DNA concentration (ng/ $\mathrm{\mu l})$

B
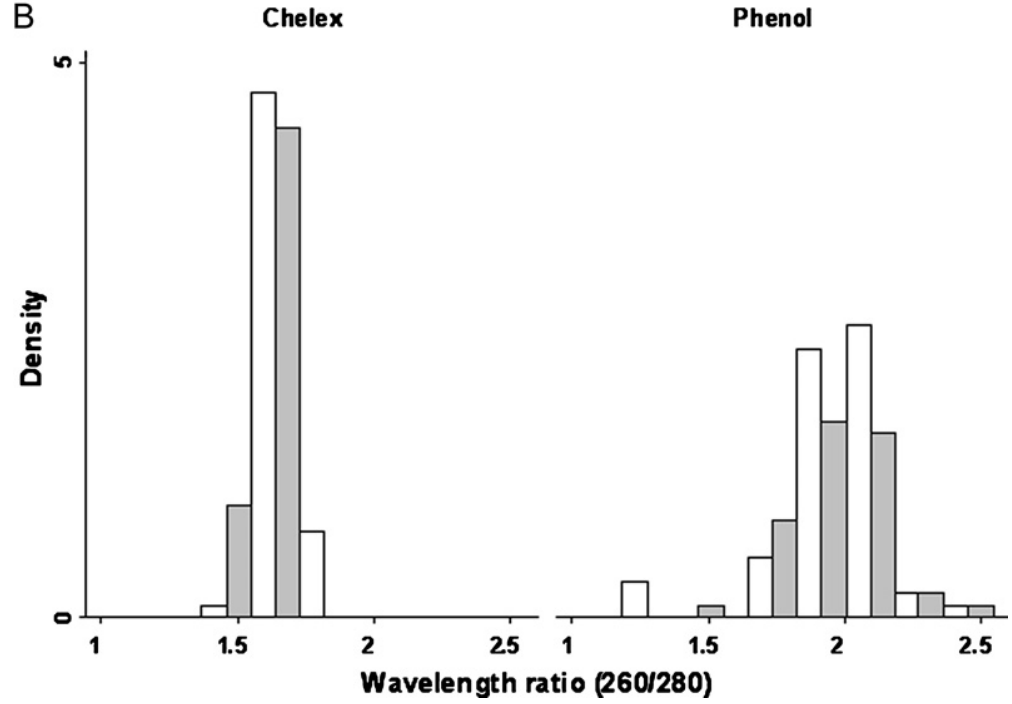

Phend

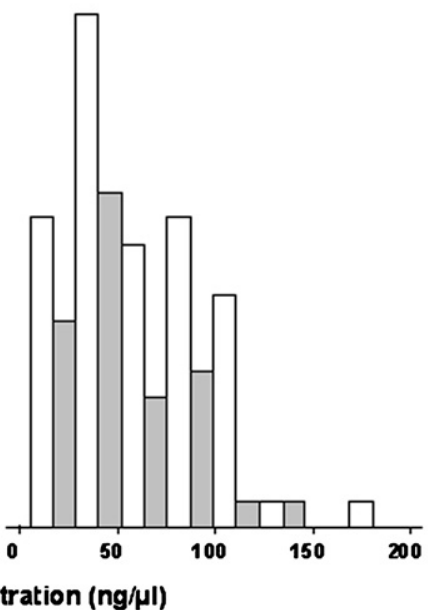

Phenol

Fig. 1. Distribution of the DNA concentration (A) and the wavelength ratio (B) in function of the extraction method used.

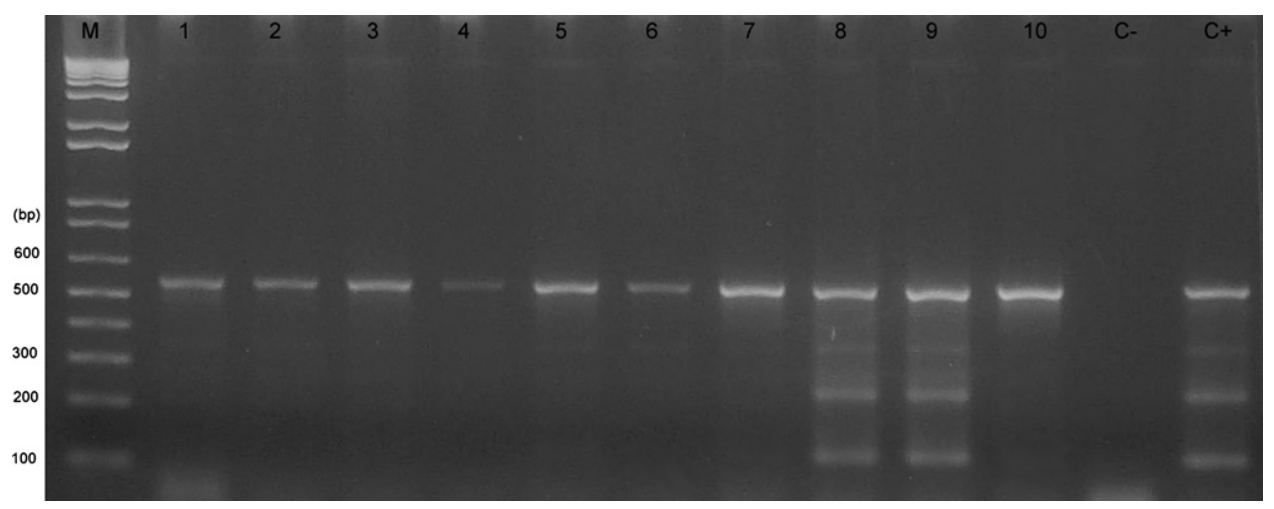

Fig. 2. Agarose gel electrophoresis following multiplex PCR on DNA pools. (M) Molecular size marker of 1000 bp; (1), (2), (3), (4), (5), (6), (7), (10) Fasciola hepatica negative pools; (8), (9) Fasciola hepatica positive pools (both dilution 1/10); (C-) negative control; (C+) positive control. 


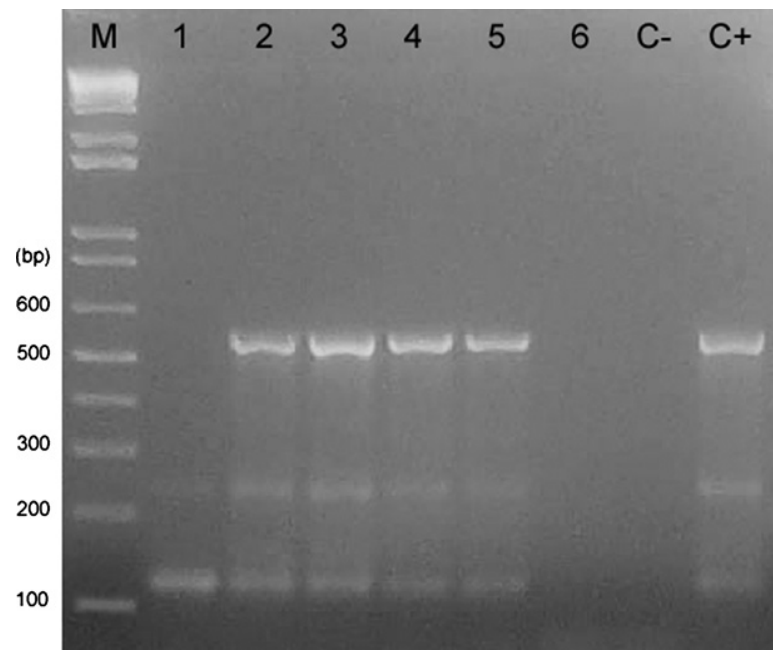

Fig. 3. Agarose gel electrophoresis following multiplex PCR for the illustration of the detection limit. Ten fold dilution of a pool (10 snails) containing only one snail naturally infected with Fasciola sp. (M) Molecular size marker of $1000 \mathrm{bp}$; (1) $1 \mu \mathrm{g}$; (2) $100 \mathrm{ng}$; (3) $10 \mathrm{ng}$; (4) $1 \mathrm{ng}$; (5) $100 \mathrm{pg}$; (6) $10 \mathrm{pg}$; (C-) negative control; (C+) positive control.

$10 \mathrm{pg}$ both signals disappeared. With undiluted material (lane 1) the internal control was absent.

When the snail DNA concentration was constant but the F. hepatica DNA was decreasing (Fig. 4), the Fasciola sp. 124 bp sequence disappeared at a DNA concentration of $100 \mathrm{fg}$ although the ITS2 band remained visible.

\subsection{Specificity}

Fig. 5 illustrates the results after amplification of DNA extracts obtained from related trematodes. No cross reactions were observed with, $D$. lanceolatum and $F$. magna. As far as P. daubneyi is concerned a band was detected between

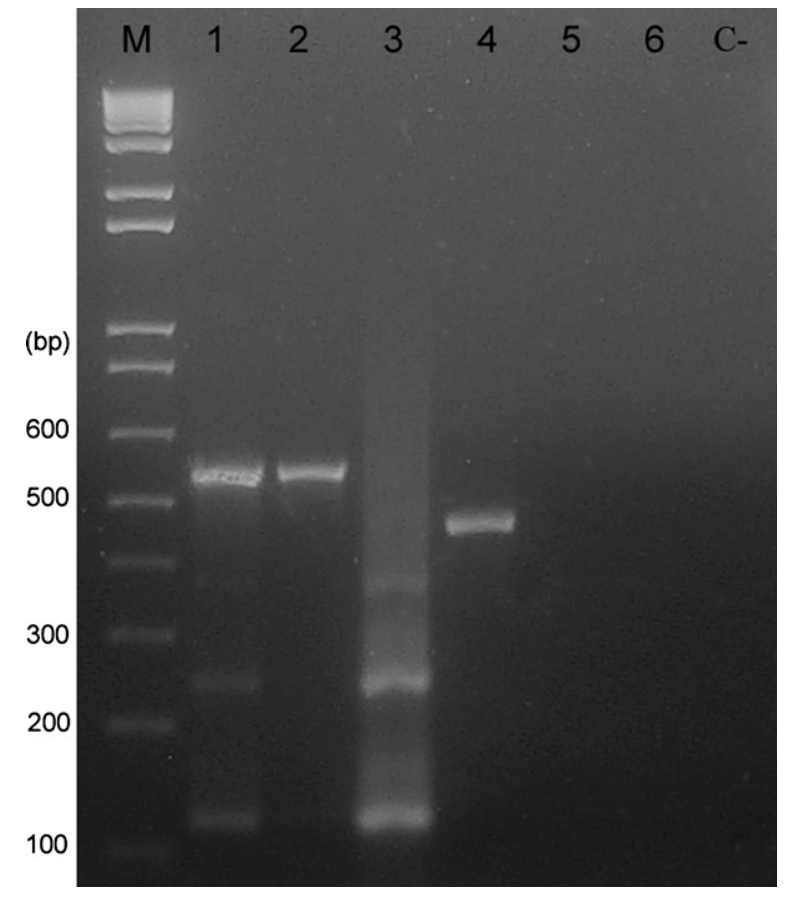

Fig. 5. Agarose gel electrophoresis following multiplex PCR for the illustration of the specificity of the assay. (M) Molecular size marker of 1000 bp; (1) DNA isolated from Fasciola hepatica naturally infested snail; (2) Non infested snail; (3) Fasciola hepatica adult; (4) Paramphistomum daubneyi adult; (5) Dicrocoelium dendriticum adult; (6) Fascioloides magna adult; $\mathrm{C}$ - negative control.

400 and $500 \mathrm{bp}$. The internal control corresponded with the ITS2 sequence of $G$. truncatula (Genbank accession no. AJ296271.1) with an identity of $99 \%$. The 124 bp sequence corresponded with the $F$. hepatica clone PFH5 genomic repeat sequence 2 (Genbank accession no. U11818.1) with an identity of $96 \%$.



Fig. 4. Agarose gel electrophoresis following multiplex PCR for the illustration of the detection limit. Each PCR tube contains a constant quantity of snail DNA and a ten fold dilution of Fasciola hepatica DNA. (M) Molecular size marker of 1000 bp; (1) 100 ng snail DNA, 100 ng Fasciola hepatica DNA; (2) 100 ng snail DNA, 10 ng Fasciola hepatica DNA; (3) 100 ng snail DNA, 1 ng Fasciola hepatica DNA; (4) 100 ng snail DNA, 100 pg Fasciola hepatica DNA; (5) 100 ng snail DNA, 10 pg Fasciola hepatica DNA; (6) 100 ng snail DNA, 1 pg Fasciola hepatica DNA; (7) 100 ng snail DNA, 100 fg Fasciola hepatica DNA; (C-) negative control; (C+) positive control. 


\section{Discussion}

This is the first reported use of the Chelex ${ }^{\circledR}$ method to extract DNA from snails. The DNA yields and purity are statistically different with the two techniques (Table 1 ). The yield of the Chelex ${ }^{\circledR}$ technique is better than the classical technique but the mean wavelength ratio for the first technique is lower than the 1.8-2 optimal ratio. This suggests that the purity of the DNA obtained by the Chelex ${ }^{\circledR}$ method is not as good as for the classical Phenol/Chloroform method. However the quality of Chelex ${ }^{\circledR}$ extracted DNA was tested in PCR and cloning/sequencing procedures with excellent results. The results show also a lower variability when using the Chelex ${ }^{\circledR}$. The Chelex ${ }^{\circledR}$ based DNA extraction is very simple, fast $(5 \mathrm{~h}$ versus $36 \mathrm{~h}$ ), and does not require organic solvents and multiple tube transfers. The extraction of snail DNA using Chelex ${ }^{\circledR}$ is, particularly regarding its time duration and its low cost, at least as efficient as the proteinase $K$ and Phenol/Chloroform extraction making this technique an excellent procedure to analyze large samples from the field.

The prevalence of $F$. hepatica in naturally infected snails is often low. Indeed, the prevalence of a natural infestation in 52,000 G. truncatula collected in the United Kingdom was estimated through microscopy to be under $2 \%$ (Ollerenshaw, 1971). Most recently this prevalence was estimated at $1.7 \%$ in France (Dreyfuss et al., 2005). Among more recently developed techniques, PCR provides the most accurate information and shows high sensitivity and specificity levels (Caron et al., 2008). However, very few studies used these techniques to assess Fasciola sp. prevalences in the field. A study in Poland, based on a PCR that amplified the same $124 \mathrm{bp}$ Fasciola sp. sequence indicated an overall prevalence of $26.6 \%$ (Kozak and Wedrychowicz, 2010). The prevalence is higher with PCR-based techniques than microscopy-based technique because of a better sensitivity of the DNA-based techniques (Caron et al., 2008). The amplification of RNA sequences was developed (Shubkin et al., 1992; Rognlie et al., 1996) but these techniques are very prone to contamination (RNAase) and time consuming.

Detection of Fasciola sp. by the multiplex PCR technique had been already applied in South America and the profiles generated shown numerous stair bands (four) referring to $F$. hepatica mitochondrial DNA (mDNA) amplification and two bands referring to F. hepatica ITS and Pseudosuccinea columella ITS (Magalhaes et al., 2004) or L. viatrix ITS (Magalhaes et al., 2008). Nevertheless, the multiplex PCR was tested on experimentally infected Brazilian snails, and the whole protocol was not easy to perform nor optimized (classical DNA extraction, high stringency conditions, no pools and silver stained polyacrylamide gels).

In an epidemiological study, it is important to avoid false negative results, particularly when the sample size is large and the estimated prevalence is low. All examined samples were easily classified as infected or uninfected, contrary to other study (Cucher et al., 2006). The multiplex PCR used in this study allows to detect possible PCR inhibitors with the use of an internal control (ITS2). When the pooled sampled were undiluted, the inhibition was complete but decreased to $30 \%$ when ten fold diluted and disappeared totally with another ten fold dilution. Concerning the individual sample, an inhibition of $70 \%$ was observed and decreased to $14 \%$ through the first ten fold dilution and disappeared with the last ten fold dilution. This suggests that pooled or individual samples should be assessed directly ten fold diluted. The presence of the internal control allowed us to avoid the use of BSA in each PCR mixture as it was previously done (Cucher et al., 2006). The ladder pattern is due to the fact that the $124 \mathrm{bp}$ sequence is tandemly repeated in the entire $F$. hepatica genome (15\%) (Kaplan et al., 1995).

The pooling of DNA is very useful particularly during large epidemiological studies, allowing to save time and money. In the present study, pools of DNA of 10 snails were used whereas in other studies up to 25 snails per pool were used (Rognlie et al., 1996). Several dilutions of pool nine (containing only one infected snails) indicated that both signals were visible up to 10,000 dilution. However with undiluted material, the internal control was undetectable and consequently an initial ten fold dilution is required. It seems that a contaminant linked to the snail DNA prevented at high concentration the amplification of the ITS2 sequence. This hypothesis is also supported by the fact that in $100 \%$ and $70 \%$ of the undiluted pools and individual samples respectively the ITS2 sequence was not amplified. The detection limit of $F$. hepatica DNA in $100 \mathrm{ng} / \mu \mathrm{l}$ of snail DNA was estimated to be one pg of $F$. hepatica DNA. This limit of detection is optimal because the minimal biological unit that infects a lymnaeid snail is a single miracidium, which contains about $0.5-1 \mathrm{ng}$ of $F$. hepatica genomic DNA (Kaplan et al., 1997). This suggests that pools of DNA of up to ten snails can be used with this protocol.

As far as the specificity of the multiplex PCR was concerned, there was no cross reaction with the three trematodes species tested. The band observed with P. daubneyi had no impact on the test interpretation. Although this band was not sequenced, alignments lead to rDNA region and further experimentations will be necessary to assess the fact that ITS2 primers could detect a snail naturally infested with P. daubneyi.

To conclude, this new DNA extraction technique based on Chelex ${ }^{\circledR}$ showed numerous advantages because it is cheaper and less time consuming. The multiplex PCR was shown to have an optimal limit of detection and specificity. The technique seems particularly suitable to assess prevalence during large epidemiological studies. Its adaptation to other lymnaeid species which could act as alternative intermediate hosts for $F$. hepatica would be very useful.

\section{Acknowledgments}

We are very grateful to Dr. Bughin (ARSIA, Ciney) for providing $D$. dendriticum individuals and Prof. A. Marinculic (Fac. Vet. Med., Croatia) for providing F. magna. The authors thank the GIGA Genomic Facility (http://www.giga.ulg.ac.be).

\section{References}

Almeyda-Artigas, R.J., Bargues, M.D., Mas-Coma, S., 2000. ITS-2 rDNA sequencing of Gnathostoma species (Nematoda) and elucidation of the 
species causing human gnathostomiasis in the Americas. J. Parasitol. 86, 537-544.

Bargues, M.D., Artigas, P., Mera, Y.S.R.L., Pointier, J.P., Mas-Coma, S., 2007. Characterisation of Lymnaea cubensis, L. viatrix and L. neotropica n. sp., the main vectors of Fasciola hepatica in Latin America, by analysis of their ribosomal and mitochondrial DNA. Ann. Trop. Med. Parasitol. 101, 621-641.

Bargues, M.D., Vigo, M., Horak, P., Dvorak, J., Patzner, R.A., Pointier, J.P., Jackiewicz, M., Meier-Brook, C., Mas-Coma, S., 2001. European Lymnaeidae (Mollusca: Gastropoda), intermediate hosts of trematodiases, based on nuclear ribosomal DNA ITS-2 sequences. Infect. Genet. Evol. $1,85-107$.

Boray, J.C., 1978. The potential impact of exotic Lymnaea spp. on fascioliasis in Australasia. Vet. Parasitol. 4, 127-141.

Caron, Y., Lasri, S., Losson, B., 2007. Fasciola hepatica: an assessment on the vectorial capacity of Radix labiata and $R$. balthica commonly found in Belgium. Vet. Parasitol. 149, 95-103.

Caron, Y., Rondelaud, D., Losson, B., 2008. The detection and quantification of a digenean infection in the snail host with special emphasis on Fasciola sp. Parasitol. Res. 103, 735-744.

Cucher, M.A., Carnevale, S., Prepelitchi, L., Labbe, J.H., Wisnivesky-Colli, C., 2006. PCR diagnosis of Fasciola hepatica in field-collected Lymnaea columella and Lymnaea viatrix snails. Vet. Parasitol. 137, 74-82.

Dagnelie, P., 1998. Statistique théorique et appliquée. Inférence statistique à une et à deux dimensions, Vol Tome 2. De Boek Université, Bruxelles, Belgique, 659 pp.

Dreyfuss, G., Vignoles, P., Rondelaud, D., 2005. Fasciola hepatica: epidemiological surveillance of natural watercress beds in central France. Parasitol. Res. 95, 278-282.

Kaplan, R.M., Dame, J.B., Reddy, G.R., Courtney, C.H., 1995. A repetitive DNA probe for the sensitive detection of Fasciola hepatica infected snails. Int. J. Parasitol. 25, 601-610.

Kaplan, R.M., Dame, J.B., Reddy, G.R., Courtney, C.H., 1997. The prevalence of Fasciola hepatica in its snail intermediate host determined by DNA probe assay. Int. J. Parasitol. 27, 1585-1593.

Ko, Y.T., Chan, M.M.Y., Ford, S.E., Fong, D., 1999. A PCR-ELISA method for direct detection of the oyster pathogen Haplospiridium nelsoni. Mar. Biotech. 1, 147-154.

Kozak, M., Wedrychowicz, H., 2010. The performance of a PCR assay for field studies on the prevalence of Fasciola hepatica infection in Galba truncatula intermediate host snails. Vet. Parasitol. 168, 25-30.

Krämer, F., 1999. Eignung einer Gensonde zum nachweis Derentwicklungsstadien von Fasciola hepatica Linne 1758 im Zwischenwirt. Tierärztliche Hoschschule, Hannover.

Krämer, F., Schnieder, T., 1998. Sequence heterogeneity in a repetitive DNA element of Fasciola. Int. J. Parasitol. 28, 1923-1929.
Krämer, F., Schnieder, T., 1999. Untersuchungen über den Zwischenwirt von Fasciola hepatica mittels einer DNA-Sonde zur Etablierung eines epidemiologischen Diagnostikverfahrens. Praktische Tierarzt $80,520-529$.

Magalhaes, K.G., Jannotti-Passos, L.K., Caldeira, R.L., Berne, M.E., Muller, G., Carvalho, O.S., Lenzi, H.L., 2008. Isolation and detection of Fasciola hepatica DNA in Lymnaea viatrix from formalin-fixed and paraffin-embedded tissues through multiplex-PCR. Vet. Parasitol. 152, 333-338.

Magalhaes, K.G., Passos, L.K., Carvalho Odos, S., 2004. Detection of Lymnaea columella infection by Fasciola hepatica through Multiplex-PCR. Mem. Inst. Oswaldo Cruz 99, 421-424.

Mostafa, O.M., Taha, H.A., Ramadan, G., 2003. Diagnosis of Fasciola gigantica in snail using the polymerase chain reaction (PCR) assay. J. Egypt. Soc. Parasitol. 33, 733-742.

Ollerenshaw, C.B., 1971. Some observations on the epidemiology of fascioliasis in relation to the timing of molluscicide applications in the control of the disease. Vet. Rec. 88, 152-164.

Rognlie, M.C., Dimke, K.L., Potts, R.S., Knapp, S.E., 1996. Seasonal transmission of Fasciola hepatica in Montana, USA, with detection of infected intermediate hosts using a DNA-based assay. Vet. Parasitol. $65,297-305$.

Schweizer, G., Braun, U., Deplazes, P., Torgerson, P.R., 2005. Estimating the financial losses due to bovine fasciolosis in Switzerland. Vet. Rec. 157. 188-193.

Schweizer, G., Meli, M.L., Torgerson, P.R., Lutz, H., Deplazes, P., Braun, U. 2007. Prevalence of Fasciola hepatica in the intermediate host Lymnaea truncatula detected by real time TaqMan PCR in populations from 70 Swiss farms with cattle husbandry. Vet. Parasitol. 150, 164-169.

Shubkin, C.D., White, M.W., Abrahamsen, M.S., Rognlie, M.C., Knapp, S.E., 1992. A nucleic acid-based test for detection of Fasciola hepatica. J. Parasitol. 78, 817-821.

Taylor, E.L., 1965. Fascioliasis and the Liver Fluke, vol. 64. FAO Agricultural Studies Edition, Rome, 253 pp.

Torgerson, P., Claxton, J., 1999. Epidemiology and control. In: Dalton, J.P. (Ed.), Fasciolosis. CABI Publishing, Wallingford, Oxon, UK, pp. 113-149.

Velusamy, R., Singh, B.P., Raina, O.K., 2004. Detection of Fasciola gigantica infection in snails by polymerase chain reaction. Vet. Parasitol. 120, 85-90.

Walsh, P.S., Metzger, D.A., Higuchi, R., 1991. Chelex ${ }^{\circledR} 100$ as a medium for simple extraction of DNA for PCR-based typing from forensic material. Biotechniques 10, 506-513.

Zhang, Z., Schwartz, S., Wagner, L., Miller, W., 2000. A greedy algorithm for aligning DNA sequences. J. Comput. Biol. 7, 203-214. 